\title{
Pengaruh Edukasi Game Puzzle Kebencanaan Terhadap Pengetahuan Mitigasi Bencana Gunung Meletus di SD Negeri Karangsalam
}

\section{The Effect of Game Puzzle Education on The Knowledge of Volcanic eruption Disaster Mitigation in SD Karangsalam}

\author{
Widia Mei Linanggita Putri ${ }^{*}$, Sri Suparti ${ }^{2}$ \\ 1,2Program Studi Ilmu Keperawatan \\ Universitas Muhammadiyah Purwokerto \\ Jl. K.H Ahmad Dahlan, Kembaran 53182, Indonesia. \\ *email: srisuparti@ump.ac.id
}

DOI;

10.30595/jrst.v4i2.6945

Histori Artikel:

Diajukan:

$10 / 03 / 2020$

Direvisi:

$16 / 09 / 2020$

Diterima:

$22 / 09 / 2020$

\section{ABSTRAK}

Bencana merupakan peristiwa atau rangkaian peristiwa yang mengancam dan mengganggu kehidupan dan penghidupan masyarakat. Anak-anak merupakan kelompok rentan terhadap bencana, menyadari adanya resiko bencana, penting ditumbuhkan kesadaran dan pengurangan resiko bencana. Pengurangan resiko bencana dapat dilakukan melalui edukasi mitigasi bencana gunung meletus di sekolah dasar. Tujuan penelitian ini untuk mengetahui pengaruh edukasi game puzzle kebencanaan terhadap pengetahuan mitigasi bencana gunung meletus Di SD Negeri Karangsalam. Penelitian ini menggunakan metode kuantitatif dengan desain quasi eksperimental dengan pendekatan pretest-posttest control group design. Populasi dalam penelitian ini adalah seluruh siswa kelas 5 SD Negeri Karangsalam, kelas 5A sebagai kelas eksperimen kelas 5B sebagai kelas kontrol. Jumlah sampel 43 responden dengan teknik total sampling. Instrument pengambilan data menggunakan lembar kuesioner, analisa data menggunakan uji Wilcoxon, uji beda Maan-Whitney. Hasil penelitian menunjukkan nilai mean pengetahuan pretest kelompok eksperimen adalah 17,05 , nilai mean kelompok kontrol adalah 15,86. Nilai pengetahuan siswa setelah edukasi pada kelompok eksperimen adalah 18,65 dan kelompok kontrol mean= 18, 19. Edukasi mitigasi bencana gunung meletus berpengaruh terhadap pengetahuan siswa SD Negeri Karangsalam ( $p$ value $=0,035$ ). Edukasi game puzzle kebencanaan meningkatkan pengetahuan mitigasi bencana gunung meletus di SD.

Kata Kunci: Game puzzle, mitigasi bencana, gunung meletus, pengetahuan

\begin{abstract}
Disasters are events or sequences of events that threaten and disrupt the lives and livelihoods of communities. Children are vulnerable to disasters realizing disaster risk, important awareness and disaster risk reduction. Disaster risk reduction can be done through the education of mountain disaster mitigation in primary school. The objective of this research to know how the educational influence of disaster Puzzle Game against the knowledge of volcano mitigation is erupted in SD. This research uses quantitative method with the design of quasi Experimentawith pretest-posttest control group Designapproach. The population in this study is all grades 5 students of SD Negeri Karangsalam, Class 5A as the experimental class of Class 5B as the control class. Number of samples of 43 respondents with total sampling technique. Instrument retrieval using questionnaire sheets, data analysis using Wilcoxon test, a different Maan-Whitney test. The research results show knowledge pretests Group for mean $=17.05$, control group mean $=15.86$. Student
\end{abstract}


knowledge after educational posttest Group of experiments mean $=18.65$ and control group mean $=18.19$. The education of mountain disaster mitigation has erupted on the knowledge of elementary school students Karangsalam ( $\mathrm{p}$ vaule= 0.035). Educational disaster puzzle game increases knowledge of volcano eruption mitigation in elementary school.

Keywords: Puzzle games, disaster mitigation, erupts mountain, knowledge

\section{PENDAHULUAN}

Dokumen Indonesia merupakan Negara yang rawan bencana. Bencana merupakan peristiwa atau serangkaian peristiwa yang mengancam dan menggangu kehiduapan dan penghidupan masyarakat yang disebabkan oleh faktor alam dalam dan faktor non alam maupun faktor manuasia sehingga mengakibatkan timbulnya korban jiwa, kerusakan lingkungan, kerugian harta benda dan dampak psikologis (Badan Nasional Penanggulangan Bencana, 2017) Gunung Slamet yang terletak di Provinsi Jawa Tengah. Gunung Slamet terletak dilima kabupaten yaitu: Kabupaten Brebes, Kabupaten Banyumas, Kabupaten Purbalingga, Kabupaten Pemalang dan Kabupaten Tegal. Berdasarkan data dari PVMBG (2014) data lutusan Gunung Slamet yang tercatat untuk pertama kali terjadi pada tahun 1772. Berdasarkan data badan penaggulangan bencana aktivitas Gunung Slamet pada tanggal 5 januari 2015 berstatus wasapada (level II), terakhir meletus Gunung Slamet berstatus waspada (level II) pada tanggal 9 Agustus 2019 hingga saat ini masih fluktuatif. Kejadian bencana erupsi gunung berapi dapat terjadi sewaktu-waktu tanpa diketahui secara pasti kapan terjadinya. Dengan adanya kejadian itu diperlukan suatu upaya pencegahan untuk mengurangi dampak yaitu dilakukan dengan mitigasi bencana. Dampak jika tidak diberikan edukasi maka kurangnya pengetahuan pada anak-anak tentang bahaya akibat gunung meletus (Sudarsono et al., 2019)

Azizah, (2018) dalam penelitiannya mengatakan anak-anak sekolah dasar kesulitan memahami materi kebencaanaan hanya dengan sosialisasi. Pemecahan masalah yang dapat diberikan adalah melalui kegiatan anak siaga bencana gunung meletus melalui metode permainan tradisional. Permainan tradisional dilakukan untuk memudahkan penyampaian materi tentang gunung meletus dan untuk menyadarkan siswa terhadap ancaman gunung meletus. Sejauh ini program pendidikan kebencanaan di sekolah baru di laksanakan untuk sekolah SMP, SMA, dan SLB, belum ada program pendidikan kebencanaan untuk sekolah SD dan kebanyakan siswa SD yang belum mengetahui tentang kebencanaan gunung meletus dan belum mengetahui tindakan yang tepat ketika ada bencana gunung meletus. Salah satu bentuk persiapan adalah mitigasi. Menurut UndangUndang Indonesia Nomor 24 tahun 2007, mitigasi adalah serangkaian upaya untuk mengurangi risiko bencana melalui pengembangan fisik dan kesadaran atau peningkatan untuk menghadapi kemampuan bencana. Menurut Sejati, Hasan, \& Hidayati, (2019) upaya mitigasi sebelum bencana dapat mengurangi dampak atau korban. Pengurangan risiko bencana menjadi program jangka panjang pemerintah Indonesia dimulai pada berbagai tingkatan, lokal dan nasional. Pusat dari manajemen risiko bencana adalah memfasilitasi kesiapsiagaan bencana di tingkat nasional, lokal, masyarakat dan pribadi, (Mustofa et al., 2019).

Penelitian yang dilakukan oleh Khatimah, (2015), menyebutkan lebih dari sebagian siswa SD memiliki pengetahuan mitigasi bencana atau kesiapsiagaan bencana yang masih rendah. Dari penelitian ini maka dilakukan edukasi Game Puzzle kebencanaan untuk meningkatkan pengetahuan mitigasi bencana Gunung Meletus, menciptakan lingkungan belajar yang menyenangkan dan menambah motivasi siswa SD untuk belajar. Selain untuk hiburan, game juga dapat digunakan untuk tujuan yang lebih serius, seperti untuk pembelajaran atau edukasi. Kelebihan game sebagai sarana pembelajaran adalah dapat memberikan pengalaman praktis yang menyenangkan sehingga dapat meningkatkan pemahaman terhadap materi pengetahuan tentang mitigasi bencana gunung meletus.

Game puzzle mempunyai tujuan yang sederhana yaitu memecahkan teka-teki dan untuk membantu proses pembelajaran pada siswa SD untuk memilih tindakan yang tepat (Haryanto \& Lakoro, 2012). Puzzle dilakukan untuk memudahkan penyampaian materi tentang gunung meletus, dilakukan untuk menyadarkan siswa terhadap ancaman gunung meletus. Sama 
halnya dengan bencana, siswa diajarkan atau tentang bagimana cara memecahkan masalah yang tepat ketika ada bencana gunung meletus dengan cara menyelamatkan diri atau bepindah tempat yang lebih aman ketika tanda-tanda gunung meletus untuk mengurangi korban jiwa dari letupan atau material vulkanik yang keluar dari gunung meletus, (Sudarsono et al., 2019). Dalam hal ini sekolah merupakan wahana efektif dalam memberikan efek untuk menyebarkan informasi, pengetahuan dan ketrampilan kepada masyarakat terdekatnya. Dengan demikian, kegiatan pendidikan kebencanaan disekolah menjadi efektif,dinamis dan implementatif dalam meningkatkan kemampuan warga sekolah, untuk mampu mengurangi dampak resiko bencana disekolah. Anak-anak usia sekolah dasar belum memiliki budaya melakukan siap siaga bencana sehingga perlu disiapkan kesiapsiagaan pada anak-anak usia sekolah terutama ditingkat dasar. Anak-anak merupakan kelompok yang rentan yang paling berisiko terkena dampak bencana, usia anak-anak sangat rentan terhadap bencana karena faktor keterbatasan kemampuan dan pengetahuan terkait dengan resiko bencana alam disekeliling dan kurangnya pemahaman tentang mitigasi bencana.

Berdasarkan data kejadian bencana dan beberapa daerah banyak korban terjadi pada usia anak sekolah baik di jam sekolah atau di jam luar sekolah. Hal ini menunjukan bahwa pentingnya pengetahuan dan pengurangan resiko bencana dan mitigasi bencana diberikan sejak dini disemua level pendidikan (Kastolani \& Mainaki, 2018) untuk memberikan pemahaman dan pengarahan langkah-langkah yang harus dilakukan saat terjadi suatu ancaman yang ada disekitarnya untuk mengurangi resiko bencana, (Indriasari, 2018). Pendidikan bencana dapat dilakukan sejak dini melalui program siaga bencana disekolah supaya anak-anak dapat mengetahui bagimana cara menyelamatkan diri saat terjadi bencana. Pendidikan siaga bencana dapat diawali pada anak usia sekolah dasar karena menurut Piaget, pada masa ini merupakan fase operasional konkrit, (Suhardjo, 2015). Hasil studi pendahuluan pada bulan September $2019 \mathrm{di}$ SD Negeri Karangsalam didapatkan data belum pernah dilakukan edukasi game puzzle kebencanaan terhadap mitigasi bencana gunung meletus disekolah. Saat dilakukan wawancara dengan 10 siswa, mereka mengatakan belum pernah mendapatkan edukasi kebencanaan mitigasi gunung meletus dan tidak tahu apa yang akan dilakukan saat terjadi bencana. Secara geografis banyak sekolah SD yang terletak didaerah rawan bencana gunung meletus seperti SD Negeri 1 Karangsalam Kecamatan Baturaden yang terletak dilereng yang rawan dengan bencana gunung meletus. Urgensi dari penelitian ini adalah sangat penting memberikan pendidikan mitigasi bencana secara dini pada kelompok rentan diantarnya anak-anak mengingat masih sedikit edukasi kebencanaan dengan fokus studi siswa-siswi SD.

\section{METODE}

\subsection{Metode dan Sampel}

Penelitian ini menggunakan metode kuantitatif dengan desain quasi eksperimental dengan pendekatan pretest-posttest control group design yaitu desain penelitian dengan membandingkan sebelum dan sesudah sehingga hasilnya dapat diketahui lebih akurat (Sugiyono, 2018). Sampel penelitian berjumlah 43 siswa yang terdiri dari 22 kelompok intervensi dan 21 kelompok kontrol. Teknik pengambilan sampel menggunakan total sampling.

\subsection{Tempat Penelitian}

Penelitian ini dilakukan di SD Negeri Karangsalam pada siswa kelas 5.

\subsection{Instrumen Penelitian}

Pada kelompok intervensi menggunakan perlakuan edukasi game puzzle dan penyuluhan mitigasi bencana sedangkan pada kelompok kontrol menggunkan perlakuan leaflet yang berisi materi mitigasi bencana gunung meletus. Etik penelitian diperoleh dari komite etik UMP dengan NO.KEPK/UMP/23/XI/2019.

\subsection{Intervensi Edukasi Game puzzle}

Pada penelitian adalah edukasi mitigasi bencana dengan media puzzle dan power point (PPT), media game puzzle terdapat point-ponit edukasi pembelajaran mitigasi bencana gunung meletus yang diambil dari web Badan Nasional Penanggulangan Bencana (BNPB). Point materi pada media puzzle dijelaskan melalui PPT melalui edukasi tentang jenis bencana, tanda peringatan dini, pra bencana, tindakan saat terjadi bencana dan pasca bencana dan langkah-langkah mitigasi bencana gunung meletus. Selanjutnya mahasiwa diberikan game puzzle dan diminta menyusun puzzle sesuai yang telah dijelaskan, sehingga pembelajaran tentang bencana gunung meletus dilakukan dengan edukasi dan game menyusun 
puzzle. Pada edukasi game puzzle setiap siswa juga melakukan atau merangkai puzzle tersebut yang sebelumnya acak menjadi runtut sesuai dengan langkah-langkah mitigasi bencana gunung meletus dengan waktu sekitar 4 menit dalam menyelesaikan penyusunan media puzzle menjadi sebuah gambar yang tepat (Gambar 1 sampai Gambar 3).

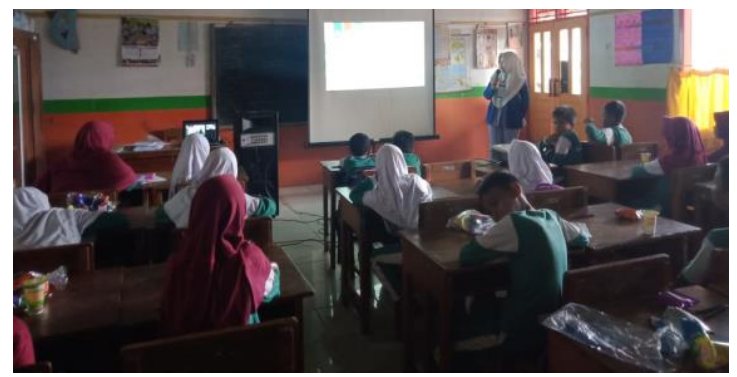

Gambar 1. Edukasi bencana dengan PPT yang dibuat dalam Game Puzzle

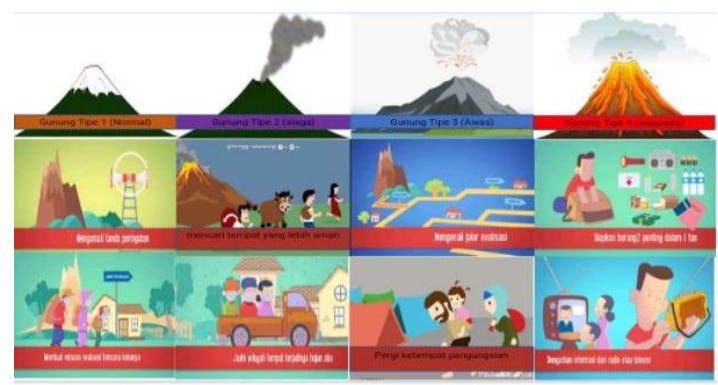

Gambar 2. Media Puzzle yang dipotong menjadi 25 potong

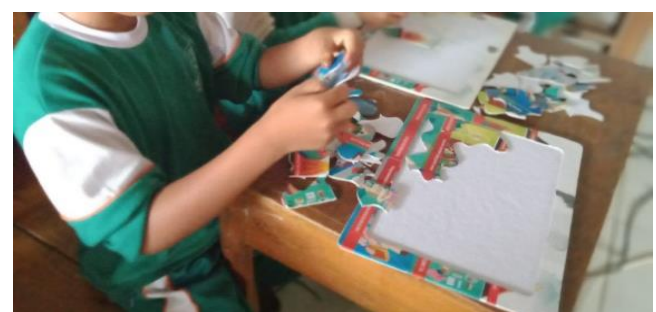

Gambar 3. Anak menyusun education game puzzle

\subsection{Analisis Data}

Instrumen dalam penelitian ini menggunakan kuesioner dan teknik pengumpulan data dengan cara pengisian kuesioner yang didilakukan sendiri oleh respoden dna dibantu peneliti. Uji validitas dilakukan di SD Negeri 1 Karangnanas dengan hasil uji R hitung $(0.496-0,674)$ lebih dari $R$ tabel $(0,444)$ sehingga kuesioner ini dikatakan valid dan uji reabilitas dengan nilai uji R hitung (0.751) lebih dari $\mathrm{R}$ tabel $(0,6)$ sehingga kuesioner ini dikatakan reliable. Analisis Data menggunakan uji Maan Whitney karena data tidka terdistribusi normal dengan nilai signifikasi $<0.05$

\section{HASIL DAN PEMBAHASAN}

\subsection{Karakteristik Responden}

Karakteristik responden penelitian mayoritas berusia 10 tahun baik itu kelompok intervensi maupun kontrol (Tabel 1).

Tabel 1. Karakteristik responden berdasarkan jenis kelamin, umur dan kelas.

\begin{tabular}{|c|c|c|c|c|}
\hline \multirow{2}{*}{$\begin{array}{l}\text { Karakteristik } \\
\text { Responden }\end{array}$} & \multicolumn{3}{|c|}{ Eksperimen } & \multirow{2}{*}{$\begin{array}{c}\text { kontrol } \\
\%\end{array}$} \\
\hline & $\mathrm{F}$ & $\%$ & $\mathrm{~F}$ & \\
\hline \multicolumn{5}{|l|}{ Jenis kelamin } \\
\hline Laki-laki & 12 & 54,5 & 10 & 47,6 \\
\hline Perempuan & 10 & 45,5 & 11 & 52,4 \\
\hline \multicolumn{5}{|l|}{ Umur } \\
\hline 10 tahun & 17 & $77,3 \%$ & 12 & 75,1 \\
\hline 11 tahun & 4 & $18,2 \%$ & 5 & 23,9 \\
\hline 12 tahun & 1 & $4,5 \%$ & 2 & 9,5 \\
\hline 9 tahun & 0 & $0 \%$ & 2 & 9,5 \\
\hline Jumlah & 22 & 100,0 & 21 & 100,0 \\
\hline
\end{tabular}

\subsection{Gambaran Pengetahuan Responden}

Berdasarkan pengetahuan diperoleh dari kuesioner yang diisi siswa sebelum dilakukan edukasi game puzzle kebencanaan mitigasi bencana gunung meletus diperoleh nilai mean \pm SD adalah $17,05 \pm 3,471$ pada kelompok intervensi dan pada kelompok kontrol adalah $15,86 \pm 3,08$. Setelah diberikan edukasi pendidikan kebencanaan mitigasi bencana gunung meletus diperoleh adanya peningkatan skor pengetahuan dengan nilai mean $\pm S D$ $18,36 \pm 2,64$ pada kelompok eskperimen $18,19 \pm 2,400$ pada kelompok kontrol. Dari hasil tersebut dapat dilihat terdapat perubahan nilai responden kearah yang lebih baik, peningkatan pengetahuan ini berpengaruh pada informasiinformasi yang responden terima dari edukasi kebencanaan mitigasi bencana gunung meletus. Semakin banyak informasi sehingga dapat meningkatkan pengatahuan responden seperti terlihat pada Tabel 2. 
Tabel 2. Tabel nilai pengetahuan pretest dan posttest edukasi game puzzle mitigasi bencana gunung meletus

\begin{tabular}{llllll}
\hline Kelompok & & \multicolumn{2}{c}{ Pretest } & \multicolumn{2}{c}{ posttest } \\
& $\mathrm{n}$ & $\begin{array}{c}\text { min- } \\
\text { max }\end{array}$ & Mean & min- & Mean \\
& & max & \pm SD \\
\hline Experimen & 22 & $11-20$ & $17,05 \pm$ & $13-20$ & $18,36 \pm$ \\
& & & 3,471 & & 2,647 \\
Kontrol & 21 & $8-20$ & $15,86 \pm$ & $8-20$ & $18,19 \pm$ \\
& & & 3,087 & & 2,400 \\
\hline
\end{tabular}

Hasil uji normalitas data dengan menggunakan uji Wilcoxon kelompok kontrol adalah 0,001 dan kelompok eksperimen 0,004 ( $p$ vaule $)<0,05$. Sedangkan pre-test post-test eksperimen berdistribusi tidak normal ( $p$ vaule) < 0,05 , sehingga analisa data menggunakan uji non parametrik yaitu Maan witney

\subsection{Pengaruh edukasi Game Puzzle}

Untuk mengetahui pengaruh edukasi mitigasi bencana dilakukan uji Maan Whitney.

Tabel 3. Uji Maan Whitney uji beda pengetahuan siswa

\begin{tabular}{lcccc}
\hline $\begin{array}{l}\text { Pengetahuan } \\
\text { mahasiswa }\end{array}$ & $\mathrm{n}$ & mean & Z hitung & P value \\
\hline $\begin{array}{l}\text { Experimen } \\
\text { Kontrol }\end{array}$ & 22 & 18.23 & -2.110 & 0.035 \\
\hline
\end{tabular}

Dari hasil uji beda Mann-Whitney pada Tabel 3, dapat dilihat bahwa nilai asymp, sig(2tailed) adalah 0,035 $<0,05$. Maka disimpulkan secara signifikan terdapat perbedaan atau pengaruh edukasi game puzzle kebencannaan terhadap pengetahuan mitigasi bencana gunung meletus di SD Negeri Karangsalam. Penelitian ini sejalan dengan pendapat Suhardjo, (2015) bahwa pendidikan siaga bencana dapat diawali pada anak usia sekolah dasar karena menurut teori Piaget pada masa ini merupakan fase operasional konkrit sehingga anak sudah siap menerima pendidikan bencanaSetelah di berikan edukasi pendidikan kebencanaan mitigasi bencana gunung meletus di peroleh hasil nilai kuesioner yang diisi siswa sessudah edukasi game puzzle kebencanan mitigasi bencana gunung meletus menunjukan bahwa kelompok eskperimen diperoleh nilai (man-max) adalah 13-20, mean \pm SD adalah 18,36 $\pm 2,647$. Sedangkan kelompok kontrol menunjukan bahwa diperoleh nilai (man-max) adalah 8-20, mean \pm SD adalah $18,19 \pm 2,400$.

Pengetahuan merupakan upaya untuk mengurangi resiko dan dampak kerugian dari bencana bahwa pengetahuan seseorang dapat meningkat karena beberapa faktor salah satunya adalah dengan memberikan informasi kepada seseorang. Informasi tersebut dapat diberikan dalam beberapa bentuk dan pemberian edukasi game puzzle mitigasi bencana gunung meletus merupakan salah satu upaya untuk memberikan informasi kepada siswa yang nantinya akan berdampak pada meningkatnya pengetahuan siswa tersebut, (Pribadi, 2014).

Salah satu cara yang dapat digunakan untuk menumbuhkan tindakan kesiapan siswa adalah penyajian metode game puzzle kebencanaan yang menerangkan bahwa game puzzle kebencanaan berisi tentang mitigasi bencana gunung meletus baik dari pra bencana hingga pasca bencana. Penggunaan media game dapat dilakukan dalam satu bidang dalam materi mitigasi bencana gunung meletus sehingga siswa lebih tertarik dalam kegiatan pembelajaran terkait dengan mitigasi kebencanaan gunung meletus, (Pribadi, 2014).

Penelitian lain yang dilakukan oleh (Steward \& Wan, 2007) tentang The Role of Simulation And Modeling In Disaster Management diperoleh hasil peran simulasi didalam manajemen bencana dapat mengukur kesiapan seseorang dalam menghadapi bencana didukung dalam penelitain (Olson et al., 2010) Olson (2010), tentang Using Gaming Simulation To Evaluate Bioterrorism And Emergency Readiness Education dengan hasil pendidikan tentang siaga bencana dengan menggunakan simulasi game atau permainan dapat memberikan hasil yang lebih baik dibandingkan yang tidak menggunakan simulasi.

Hasil penelitian ini sesuai dengan pendapat (Wawan, 2012) bahwa faktor yang mempengaruhi tingkat pengetahuan seseorang berasal dari informasi yang diterimanya, dengan sumber informasi yang lebih banyak akan meningkatnya pengetahuan sehingga lebih luas, (Notoatmodjo, 2012) pengetahuan merupakan hasil dari tahu yang terjadi setelah seseorang melakukan pengindraan terhadap objek tertentu, pengindraan terjadi melalui pengindraan manusia, yakni indera penglihatan, pendengaran, penciuman, rasa dan raba. Pendidikan edukasi mitigasi bencana dapat meningkatkan pengetahuan bencana siswa, pelaksanaan edukasi kebencanaaan pada siswa dalam penelitian ini menggunakan metode pada kelas eksperimen metode ceramah dengan media power point dan simulasi game puzzle 
kebencanaan, sendangkan pada kelas kontrol menggunakan metoden leaflet, (Notoatmodjo, 2012).

Hasil penelitian ini sejalan dengan penelitian yang dilakukan oleh (Asna Afifah, Vina, Istichomah, Priyantari, 2015) yang menunjukan adanya pengaruh yang signifikan antara sebelum dan sesuadah diberikan penyuluhan tentang kesiapsiagaan menghadapi bencana. WHO mengugkapkan, bahwa sikap seseorang disebabkan oleh pemikiran dan perasaan dalambentukpengetahuan, persepsi, sikap, kepercayaan, dan penilaian-penilaian seseorang terhadap objek. Dalam dalini, pemberian penyuluhan kesehatan, maka pengetahuan akan bertambah, sehingga sikap juga akan lebih baik lagi, (Mais et al., 2015).

Bencana gunung meletus bukanlah hal yang baru ditelinga responden karena seluruh responden dalam penelitian ini berasal dari daerah yang rawan gunung meletus. Hasil keseluruhan yang diperoleh dalam penelitian ini peneliti beramsumsi bahwa dengan memperhatikan karakteristik responden, faktorfaktor yang mempengaruhi pengetahuan responden mendapatkan paparan informasi dari televisi atau kajian mengenai pendidikan kebencanaan dan media yang sesuai dengan responden. Sejalan dengan penelitian (Cui et al., 2018) menyebutkan bahwa orang yang menerima pendidikan bencana akan memiliki persepsi ketahanan masyarakat yang lebih tinggi dari pada tidak menerima pendidikan kebencanaan.

Dengan memperhatikan karakteristik responden, faktor-faktor yang mempengaruhi pengetahuan dan media sesuai dengen responden, edukasi game puzzle mitigasi bencana gunung meletus dapat memberikan pengaruh terhadap pengetahuan bencana gunung meletus pada siswa SD Negeri Karangsalam kelas 5. Edukasi melaui media PPT dan menuangkanya dalam model game puzzle menjadia tantangan bagi responden untuk menyelesaikan game puzle yang sekaligus belajar tentang kebencanaan sehingga meningkatkan aspek kognitif dan psikomotor reponden sehingga pengetahuan baru akan diperoleh. Hal ini dibuktikan bahwa setelah mendapatkan eduaksi mitigasi bencana gunung meletus terjadi peningkatan pengetahuan siswa tentang bencana gunung meletus.

\section{KESIMPULAN}

Edukasi game puzzle kebencanaan meningkatkan pengetahuan mitigasi bencana gunung meletus di SD. Edukasi kebencanaan melaui game puzle yang berupa tantangan permainan menyusun puzle memberikan stimulasi kognitif dan psikomotor sehingga pengetahuan baru dapat diterima oleh anak anak.

\section{UCAPAN TERIMA KASIH}

Terima kasih kepada responden, kepala sekolah SD Negeri Karangsalam yang memberikan izin kepada peneliti sehingga dapat melakukan penelitian di lingkungan sekolah dasar dan juga Fakultas Ilmu Kesehatan Univeristas Muhammadiyah Purwokerto.

\section{DAFTAR PUSTAKA}

Asna Afifah, Vina, Istichomah, -, Priyantari, W. (2015). Pengaruh Pendidikan Kesehatan Tentang Kesiapsiagaan Bencana Gempa Bumi Terhadap Pengetahuan Siswa Di SDN Patalan Baru Kecamatan Jetis Kabupaten Bantul. Jurnal Kesehatan SAMODRA ILMU , 2015, 2015.

Azizah, Azizah, and M. T. P. M. M. (2018). Efektivitas Media Permainan Monopoli Materi Erupsi Gunung Berapi terhadap Tingkat Pengetahuan Bencana pada Ekstrakurikuler Sekolah Siaga Bencana di SMP Negeri 1 Delanggu Kabupaten Klatenitle. Universitas Muhammadiyah Semarang.

Badan Nasional Penanggulangan Bencana. (2017). Buku Pedoman Latihan Kesiapsiagaan Bencana. Jurnal Kajian Komunikasi. https://doi.org/10.24198/jkk.v1i1.6031

Cui, K., Han, Z., \& Wang, D. (2018). Resilience of an earthquake-stricken rural community in southwest china: Correlation with disaster risk reduction efforts. International Journal of Environmental Research and Public Health.

https://doi.org/10.3390/ijerph15030407

Gil, H. W., Bang, K., Lee, S. Y., Han, B. G., Kim, J. K., Kim, Y. O., Song, H. C., Kwon, Y. J., \& Kim, Y. S. (2014). Efficacy of hemocontrol biofeedback system in intradialytic hypotension-prone hemodialysis patients. 
Journal of Korean Medical Science. https://doi.org/10.3346/jkms.2014.29.6.8 05

Haryanto, H., \& Lakoro, R. (2012). Game Edukasi “ Evakuator " Bergenre Puzzle Dengan Gameplay Berbasis Klasifikasi Sebagai Sarana. Techno.COM, 11(1), 47-54. http://publikasi.dinus.ac.id/index.php/tec hnoc/issue/view/65

Indriasari, F. N. (2018). Pengaruh Pemberian Metode Simulasi Siaga Bencana Gempa Bumi terhadap Kesiapsiagaan Anak di Yogyakarta. Jurnal Keperawatan Soedirman. https://doi.org/10.20884/1.jks.2016.11.3. 700

Kastolani, W., \& Mainaki, R. (2018). Does Educational Disaster Mitigation Need To Be Introduced In School? SHS Web of Conferences, 42, 00063. https://doi.org/10.1051/shsconf/2018420 0063

Khatimah, H., Sari, S. A., \& Dirhamsyah, M. (2015). Pengaruh Penerapan Metode Simulasi School Watching Terhadap Sikap Kesiapan Siswa Dalam Menghadapi Bencana Gempa Bumi. Jurnal Ilmu Kebencanaan.

Mais, P., Mulyadi, N., \& Lolong, J. (2015). PENGARUH PENYULUHAN BAHAYA GUNUNG BERAPI TERHADAP KESIAPSIAGAAN SISWA SMP KRISTEN KAKASKASEN KOTA TOMOHON MENGHADAPI BENCANA GUNUNG BERAPI. Jurnal Keperawatan UNSRAT.

Mustofa, T., Muryani, C., \& Yusup, Y. (2019). Knowledge Enhancement and Mitigation Strategy of Volcano Eruption Disaster Based using Macromedia Flash Media. https://doi.org/10.4108/eai.27-42019.2286925

Notoatmodjo, S. (2012). Promosi Kesehatan dan Perilaku Kesehatan (edisi revisi 2012). In Jakarta: rineka cipta.

Olson, D. K., Scheller, A., Larson, S., Lindeke, L., \& Edwardson, S. (2010). Using gaming simulation to evaluate bioterrorism and emergency readiness education. Public Health Reports. https://doi.org/10.1177/0033354910125 00316
S.Pribadi, K. dkk. (2008). Buku Pegangan Guru Pendidikan Siaga Bencana. . Bandung: Institut Teknologi Bandung.

Sejati, A. E., Hasan, M., \& Hidayati, D. N. (2019). The level participation in efforts mount Kelud eruption disaster mitigation in East Java. Harmoni Sosial: Jurnal Pendidikan IPS. https://doi.org/10.21831/hsjpi.v6i1.2784 7

Steward, D., \& Wan, T. T. H. (2007). The role of simulation and modeling in disaster management. Journal of Medical Systems. https://doi.org/10.1007/s10916-0069047-7

Sudarsono, B., Yuwono, B. D., Ramadhan, F., Teknik, D., Universitas, G. T., \& Bencana, P. M. (2019). Analisis Sebaran Aliran Lava Untuk Pembuatan. 02(01), 28-35.

Sugiyono. (2018). Metode Penelitian Kombinasi (mixed Methods). In International Journal of Physiology.

Suhardjo, D. (2015). ARTI PENTING PENDIDIKAN MITIGASI BENCANA DALAM MENGURANGI RESIKO BENCANA. Jurnal Cakrawala Pendidikan.

https://doi.org/10.21831/cp.v0i2.4226

Wawan. (2012). Pengetahuan, Sikap dan Perilaku Manusia. In Syafni. https://doi.org/doi: 10.1023/B:HYDR.0000008590.37567.fa 